\title{
A vision for peace in the City of Tshwane: Insights from the homeless community
}

\begin{tabular}{|c|c|}
\hline \multicolumn{2}{|c|}{$\begin{array}{l}\text { Authors: } \\
\text { Lukwikilu Mangayi }^{1} \\
\text { Themba Ngcobo }{ }^{1}\end{array}$} \\
\hline \multicolumn{2}{|c|}{$\begin{array}{l}\text { Affiliations: } \\
{ }^{1} \text { Department of Christian } \\
\text { Spirituality, Church History } \\
\text { and Missiology, University of } \\
\text { South Africa, South Africa }\end{array}$} \\
\hline \multicolumn{2}{|c|}{$\begin{array}{l}\text { Note: } \\
\text { Rev. Lukwikilu Mangayi is a } \\
\text { community engaged action } \\
\text { researcher and leader of } \\
\text { the Meal of Peace project of } \\
\text { the Department of Christian } \\
\text { Spirituality, Church History } \\
\text { and Missiology in the College } \\
\text { of Human Sciences at the } \\
\text { University of South Africa. He } \\
\text { is a member of the research } \\
\text { team on 'Public Urban } \\
\text { Theology in South Africa' and } \\
\text { a member of the research } \\
\text { team on 'finding pathways } \\
\text { out of homelessness in South } \\
\text { Africa'. Rev. Themba Ngcobo } \\
\text { is a lecturer and is involved in } \\
\text { the Meal of Peace Project of } \\
\text { the Department of Christian } \\
\text { Spirituality, Church History } \\
\text { and Missiology in the College } \\
\text { of Human Sciences at the } \\
\text { University of South Africa. }\end{array}$} \\
\hline \multicolumn{2}{|c|}{$\begin{array}{l}\text { Correspondence to: } \\
\text { Lukwikilu Mangayi }\end{array}$} \\
\hline \multicolumn{2}{|c|}{$\begin{array}{l}\text { Email: } \\
\text { mangal@unisa.ac.za }\end{array}$} \\
\hline \multicolumn{2}{|c|}{$\begin{array}{l}\text { Postal address: } \\
\text { PO Box 392, University of } \\
\text { South Africa, Pretoria 0003, } \\
\text { South Africa }\end{array}$} \\
\hline \multicolumn{2}{|c|}{$\begin{array}{l}\text { Dates: } \\
\text { Received: } 26 \text { June } 2015 \\
\text { Accepted: } 29 \text { July } 2015 \\
\text { Published: } 13 \text { Nov. } 2015\end{array}$} \\
\hline \multicolumn{2}{|l|}{ Read online: } \\
\hline 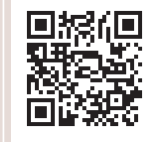 & $\begin{array}{l}\text { Scan this QR } \\
\text { code with your } \\
\text { smart phone or } \\
\text { mobile device } \\
\text { to read online. }\end{array}$ \\
\hline
\end{tabular}

Communities living on the margins of society, such as the homeless, are overlooked in the process of building a vision for peace in the City of Tshwane. This article, therefore, seeks to explore the issue of a vision for peace from the perspective of the homeless in the City of Tshwane. Isaiah 65:17-25 was used as a hermeneutic key, within a community engaged action research framework, to stimulate reflection and application in the context of homelessness where meaningful peace is non-existent. Emerging voices of ordinary readers (participants) of the text, as represented by the homeless in the City of Tshwane (CoT), suggest institutions (of education, business, government, churches as well as other individuals) need to work together in synergy towards the realisation of this peace in the city. In relation to peace in the $\mathrm{CoT}$, this research has unearthed some insights from a local homeless community which could contribute towards the development of an integrated praxis needed for transformative urban missiology. The recommendations derived from the research are: the homeless people must be partisans to such a holistic and integrated vision for peace and should be seen as active responsible citizens of the city willing to undertake actions that are in support of this vision.

\section{Introduction}

'... join us in this relentless and irrevocable journey to the kingdom of a better life for all citizens of the metropolitan City of Tshwane'. With these words the executive Mayor of the City of Tshwane (CoT), Councillor Ramokgopa, concluded his 2014 State of the Capital City Address (City of Tshwane 2014:23). Although the address from the first citizen of the city implies a vision of peace for all, it is a dream yet to be realised. The following questions could be asked: What is peace? What does a vision for peace entail? Pope Francis gives an idea of answers that are relevant to the question:

Peace in society cannot be understood as pacification or the mere absence of violence resulting from the domination of one part of society over others. Nor does true peace act as a pretext for justifying a social structure which silences or appeases the poor, so that the more affluent can placidly support their lifestyle while others have to make do as they can. Demands involving the distribution of wealth, concern for the poor and human rights cannot be suppressed under the guise of creating a consensus on paper or a transient peace for a contented minority. The dignity of the human person and the common good rank higher than the comfort of those who refuse to renounce their privileges. When these values are threatened, a prophetic voice must be raised. (Francis [Pope] 2013:168)

The biblical vision for peace in the world is more than just safety and peaceful coexistence. Certainly, more than just peace is needed for communities such as the homeless in the CoT, who are living on the margins of society, in order to become part of the city in meaningful ways. The City of Tshwane regards the following people as homeless:

[A]ll people living on the streets who fall outside of a viable social network of assistance and who are not able to provide themselves with a shelter at any given time and place. (City of Tshwane 2013:21)

Thus, the kind of peace described by the Pope which is not only holistic and multidimensional, but also resonates with ultimate goals for a contextual missiology aimed at transformation, if realised, will yield concrete improvements.

The biblical concept for peace in Hebrew is shalom. It involves justice amongst people as a result of integral development (Chu Ilo 2011:98) and the breaking-off of all kinds of shackles. It has also to do with bringing all people in society to act as committed and responsible citizens. Based on the respect for the rights of people, the cries of the entire population, especially people on the margins of society, must be heard. From a Missiological perspective it is, therefore, essential

How to cite this article: Mangayi, L. \& Ngcobo, T., 2015, 'A vision for peace in the City of Tshwane: Insights from the homeless community', HTS Teologiese Studies/Theological Studies 71(3), Art. \#3097, 9 pages. http://dx.doi.org/10.4102/hts.v71i3.3097

Copyright: @ 2015. The Authors. Licensee: AOSIS OpenJournals. This work is licensed under the Creative Commons Attribution License. 
for the sake of peace to point out new forms of poverty and vulnerability, in which we are called to recognise the suffering Christ. One of the new forms of poverty on our doorsteps is the predominantly black face of homelessness in our cities. Further, from a Missiological perspective, the homeless include both foreign refugees and indigenous people; some people with addictions and some elderly who are increasingly isolated and abandoned and many others who could also take centre-stage in the process of peace building in society.

It was, therefore, our aim in this article to communicate the wishes and desires of the homeless community about peace in the CoT. Using Isaiah 65:17-25 as a hermeneutic key, we seek to explore the issue of vision for peace from the perspective of the homeless in the CoT. Central to this community engaged research is the question: What will the insights be from a homeless community about a vision for peace in the CoT? We argue that these insights contributed towards the development of an integrated praxis needed for transformative urban missiology in the CoT.

The research on which this article reports includes, firstly, the research methodology; secondly, some theological reflection; thirdly, encounterological reflection; fourthly, a synthesis (emerging voices); and, fifthly, a conclusion and recommendation. According to Kritzinger (2008:780), an approach in encounterology requires:

1. 'a holistic and reflexive process that considers seven different dimensions of the encounter'

2. 'a dialogical approach in which a Christian enters into a journey of mutual witness with a follower of another faith' (p. 780).

\section{Research methodology}

The research was conducted within an action research framework. Twelve participants, using the Isaiah 65:17-25 texts, were involved in Contextual Bible Study (CBS) on 20 May 2014 at Tshwane Leadership Foundation headquarters in Tshwane. These participants, five men and seven women, were from the homeless community that is associated with Tshwane Leadership Foundation. They voluntarily consented to participate in this study. Further, these participants were black Africans, homeless and unemployed and were able to read and write in English. Reflections were based on Isaiah 65:17-25 (Modern King James Version):

17 For, behold, I create new heavens and a new earth. And the things before will not be remembered, nor come to mind. 18 But be glad and rejoice forever in that which I create; for behold, I create Jerusalem a rejoicing, and her people a joy. 19 I will rejoice in Jerusalem, and I will rejoice in My people; and the voice of weeping will no more be heard in her, nor the voice of crying be heard in her. 20 There will not be an infant, nor an old man that has not filled his days. For the child will die a hundred years old; but the sinner who is a hundred years old will be despised. 21 And they will build houses and live in them; and they will plant vineyards and eat their fruit. 22 They will not build, and another live in them; they will not plant, and another eat. For like the days of a tree are the days of My people, and My elect will long enjoy the work of their hands. 23 They will not labour in vain, nor bring forth for terror. For they are the seed of the beloved of the LORD, and their offspring with them. 24 And it will be, before they call I will answer; and while they are still speaking, I will hear. 25 The wolf and the lamb will feed together, and the lion will eat straw like the ox; and dust will be the food of the snake. They will not hurt nor destroy in all My holy mountain, says the LORD.

In the process of the Contextual Bible Study (CBS), the Bible is read as 'a resource for social and individual transformation' (West \& Ujamaa Centre Staff 2011:3). CBS is a methodology developed by West and the Ujamaa staff to carry out this transformation. CBS, as one of the ways of reading the Bible collectively in groups, has its 'origins in the interface between socially engaged biblical scholars, organic intellectuals, and ordinary Christian "readers" (whether literate or not) of the Bible' (West \& Ujamaa Centre Staff 2011:2-3). These biblical scholars and organic intellectuals are referred to as 'trained readers' whilst ordinary Christians (whether illiterate or not) are referred to as 'ordinary readers' of the Bible in the language of CBS.

CBS is a See-Judge-Act (West \& Ujamaa Centre Staff 2011:3) method of reading the Bible. In relation to this study, participants (i.e. ordinary readers), in groups of four, read Isaiah 65:17-25. Based on this text, the process began with an analysis of the participants' local context (See). Then participants re-read the Bible to allow the biblical text to speak to the context (Judge). They then moved to action as they responded to what God was saying (Act). The following questions guided their encounters:

1. What is this text about?

2. Who are the intended readers?

3. What does God intend to do? Why?

4. What are the things or issues in our context which need to be changed for the better? Why?

5. How does the work of God change the situations or conditions of the people?

6. What could we learn from how God works to change people's situations or conditions?

7. Drawing from God's vision, what could be done to have peace in our city?

8. What could you do in support of these actions?

Participants' inputs to these questions are tabled under encounterological reflection. Later, as part of the article, these inputs will be in critical dialogue with theological reflection commonly undertaken by trained readers of the Bible.

\section{Theological reflection on Isaiah 65:17-25}

A theological interpretation of Isaiah 65:17-25, on the issue of God's vision for peace in the city, should be placed within the broader context of the Old Testament scope regarding prophetic utterances. However, it will be difficult within the limited scope of this article to delve deeply into the exegetical substance of the text, but an attempt will be made 
to highlight some biblical principles and guidelines about the issue of peace as related to this text. Prominent amongst these principles and guidelines are issues such as:

1. believers as peacemakers

2. YHWH as a warrior for peace for his people

3. peace as an activity of God

4. peace leads to collective wellbeing of creation.

According to Davidson, Stibbs, and Kevan (1965:606) and Webb (1997:244), the first seven verses of the chapter (65) amplify the theme of resolute failure of the people to answer the divine call, and the relationship between this and the trials they are facing. On the other hand, verses 8 to 25 capture a promise of glorious restoration: 'the coming of God's kingdom' (Webb 1997:244). In the impending judgement, the faithful will be secured (8-10), whilst the faithless will be utterly cast off (11-15). The chapter then moves forward to a description of the prosperity that is yet to come to Jerusalem and the people of God when His purpose is fulfilled. New heavens and new earth (17) will be created; new inheritors of the grace of Jehovah will inhabit them. Restored in spirit, man will find himself in a world transfigured, and sorrow and weeping shall be done away (19). Moreover, this text pronounces peace as:

1. an activity of God who changes situations both in a broader and narrow scale (vv. 17-18a)

2. the restoration of joy where pain and loss do not exist (vv. 18b-22)

3. assurance of prosperity (v. 23)

4. the welfare of all the city residents (v. 25).

The similarities between $65: 17-25$ and 11:6-9 could be better understood in relation to this context.

\section{Context}

Isaiah, together with other eighth century $\mathrm{BCE}$ prophets such as Amos, Hosea and Micah lived at a time when idolatry was ripe in Israel (Hs 2:16; 4:12-14; 4:17 and 13:2). Utley (2010:29) states that it was a time of economic prosperity and military expansion for both Israel and Judah (see also Webb 1997:20). However, this prosperity was beneficial only to the wealthy class. The poor were exploited and abused. It was that moment when 'the buck and the gun' (Utley 2010:29) became idols! The wealthy class benefited greatly at the expense of the poor as a result of long and prosperous reigns of Jeroboam II (786-746 BCE) in the North and Uzziah (783-742 BCE) in the South. According to Beyer (2007:30) the Assyrians's conquest of Syria, the absence of conflict between Israel and Judah, and taxation and exploitation of trade routes in addition to the use of dishonest means such as the bribery of the judiciary and the falsification of commercial weights, contributed also to the prosperity of the wealthy class.

We deduce, therefore, that the power dynamics and injustices highlighted in the foregoing paragraph made the life of the poor and marginalised miserable. Against this backdrop,
Isaiah's message was one of radical universal monotheism and a redemptive plan for all creation with chapters 56-66 depicting the future Messianic kingdom of peace - 'the grand finale of God's restoration' (Beyer 2007:229-242).

\section{Peace and its manifestation}

Peace is one the basic and necessary components of human existence. In this text, the contours of peace equal to that of a new world opened up in 'ever-widening circles: from the mountains, plains and valleys of a renewed Palestine (vv. 9-10) to the new heavens and a new earth (v. 17), with a new Jerusalem at its centre (v. 18) 'a cosmic paradise ...' (v. 25) (Webb 1997:244). It is a peace that is manifested in all spheres of life in the world.

Scholars such as Utley (2010) have elaborated on the distinctive understanding of peace between nations. $\mathrm{He}$ explains that peace for the Greeks was as follows:

[It was a] society of order and coherence, but for the Romans it was the absence of conflict brought about through the power of the state; however, peace for the Hebrews was always viewed as a gift of YHWH based on humankind's proper response to him. (Utley 2010:84)

The latter understood peace on the basis of a Hebrew word, shalom. This understanding is shared in Judeo-Christianity faith communities as peace has mostly been understood in terms of that Old Testament Hebrew word, shalom.

Shalom interpretatively means completeness, soundness and wellbeing (Wood [1962] 1996:891). It is understood to provide stability in the community and prosperity for all. However, it is not only based on prosperity, but divine security and protection as well. Hence, Wood ([1962] 1996:891) explains that shalom is used:

1. when one prays for the welfare of another (Gn 43:27; Ex. 4:18; Jdg. 19:20)

2. when there is harmony between individuals (Jos 9:15; 1 Ki 5:12)

3. when one seeks and strives for the good of the city or nation (Ps 122:6; Jr 29:7)

4. as a reference to material prosperity (Ps 122:6)

5. as a reference to physical safety and healing (Ps 4:8).

Wolterstorff (1983:69) defines that 'shalom is the human being dwelling at peace in all his or her relationships: with God, with self, with fellows, with nature.'

In relation to this explanation, Isaiah 65:17-25 depicts a vision of peace which is all-inclusive that seeks to transform everybody, everything and everywhere for the better. Ryken and Longman (1995:632) wrote that it means a 'state of the fullest flourishing in every dimension (physical, emotional, social, and spiritual) because all relationships are right, perfect, and filled with joy' (see also Durham \& Porter 1970:280). With particular reference to verses 20-25 Campolo (2008:31) writes, 'Isaiah pointed to what the Kingdom of peace would look like' where death and sorrow 
will not exist. The forms of shalom depicted in this passage include spiritual, psychological, social and physical shalom (Keller 2010:173-174). However, it is important to note that peace is not finely defined in this text, but embodied within the context of hope as associated with justice. Peace is, therefore, understood as the product of justice. Thus, drawing from Old Testament material, we see $\mathrm{YHWH}$ as a warrior for peace on behalf of his people (cf. Joshua to Judges and Is 59:17). He is the one who enforces justice and the restoration of peace. Therefore, shalom manifests itself through justice and restores hope. Wolterstorff (1983:70) rightly summed it up when he said: 'To dwell in shalom is to enjoy living before God, to enjoy living in one's physical surroundings, to enjoy living with one's fellows, to enjoy life with oneself'.

\section{Peace, hope and social justice}

In the context of this text, the majority of ordinary Israelites were marginalised and excluded by the dominant group in terms of power and access to wealth. As a result, these people were hopeless as they suffered social injustice. Hence, the vision of new heavens and a new earth, with the God of justice as the main actor, 'invites hopeless people to act with hope' (Brueggemann 1987:83). Further, this hope was about 'a new world of justice, equity, freedom and wellbeing' (Brueggemann 1987:80). This

new world will be history perfected and paradise regained, ... joy (18), fullness of life (20), security (21-23a), rewarding work (22b), fellowship with God (23b-24) and peace (25). (Webb 1997:245)

Notably, people on the margins of society such as the homeless dream about such things which will break off the shackles of injustice, inequality and poverty that currently bind them. These dreams of alternative reality often lead to hoping for something better which is peace in all spectrums of life as portrayed in Isaiah 65.

By implication, this biblical scripture invites all those who love peace to co-work with YHWH for the realisation of his kingdom of peace which culminates in a 'new earth and new heavens'. For the sake of peace now and with reference to homelessness, in the words of Corbett and Fikkert (2012: 105-106), this co-working will, in essence, be about 'doing relief and rehabilitation, developmentally'. Therefore, we argue in relation to God's vision of peace articulated in Isaiah 65:17-25, the homeless in Tshwane in the here and now need relief; that is, an appropriate love response must be given to their needs for shelter, food and protection. They also need rehabilitation, which entails working with them as responsible citizens of Tshwane in the transformation of their situation, thus breaking off the shackles that still bind them 20 years on after democracy.

Further, it is preferable for these relief and rehabilitation processes to be holistic and integrated in philosophy and praxis, for them to become the 'good news' of the kingdom of peace.

\section{God's love and peace}

The good news of the kingdom of peace is the manifestation of God's love in the whole spectrum of life. From a public theology perspective, Koopman (2010:123) elaborates, 'God's love for the world, which comes to expression in the magnalia Dei (that is the marvels and the mighty acts of God), does have meaning, significance, and implications for all dimensions and terrains of life, from the most private, personal, and intimate to the most public, open, social, and cosmic.' Concretely, the evidence of this love is depicted in

the acts of creation, sustenance, care, election, and calling of God the Father/Mother/Parent; in the acts of reconciliation, salvation, and liberation of God the Son; and in the acts of renewal, fulfilment, and perfection of God the Spirit. This triune work establishes, confirms and actualises the dignity and worth of all humans and of the rest of creation. (Koopman 2010:23)

This is in essence the peace that God intends to bring to the creation that he loves dearly.

Therefore, we are convinced that magnalia Dei is at the core of God's vision for peace, depicted in Isaiah 65:17-25, in that it is God's nature of love which, at the face of misery and suffering of his people, makes him declare 'behold, I create new heavens and a new earth'. Change agents have the responsibility to co-work with God for the realisation of this vision.

In the same vein, the World Council of Churches (1990) aptly made 10 affirmations on Justice, Peace and the Integrity of Creation. Two of these, namely affirming God's option for the poor and affirming the peace of Jesus Christ, seek to encourage believers in the crucified and risen Christ to perform a reconciling role in the world. This role entails that to be makers of peace there is the need for the conscious acceptance of vulnerability. In relation to this article, it implies embracing the biblical mandate of solidarity with the poor, as portrayed by Jesus Christ in the New Testament. It is about doing justice which 'means to go to places where the fabric of shalom has broken down, where the weaker members of societies are falling through the fabric, and to repair it' (Keller 2010:177; see also Koehler et al. 1994). This call is implied in Jeremiah 29:7 to 'seek the peace and prosperity of the city'. In the New Testament, Christ is reconciling all things to himself. $\mathrm{He}$ is bringing all things in heaven and earth together in Christ (Col 1:20; Eph 1:10) in perfect harmony, as exhibited in Isaiah 65:17-25.

Admittedly, the New Testament material about makers of peace may not advocate a detailed answer to social evils in terms of political theory or action, but it is mainly associated with spiritual redemption. The focus is not on physical battles, but on the spiritual battle between light and dark, goodness and evil, love and hate, God and Satan (Eph 6:10-17). Hence, in the New Testament, peace is largely seen as an attitude of the heart amidst problems of the world. It is related solely to our relationship with Christ (Rm 5:1; Jn 14:27), not the state. The peacemakers of Matthew 5:9 are not 
political, but proclaimers of the gospel. This view narrows down the implications of Isaiah 65:17-25 to a mistaken view which equates the Church to the kingdom of God and as the only beneficiary of God's peace portrayed in Isaiah 65 (see the 19th Century Bible commentaries of Thomas Scott [1866] and Adam Clarke [1832]).

As a result, we observed that some scholars and practitioners tend to opt for the hermeneutics of these Bible commentators and that of the New Testament, and neglect to consider insights from the Old Testament as a whole on themes such as peace, hope and liberation. In contrast, Bible-centred contextual scholars seek to consider insights from both the Old Testament and the New Testament in their praxis in relation to working for peace. They are inspired by $\mathrm{YHWH}$ to become warriors for peace, not with guns but through advocacy, prophetic witness and by enhancing human dignity above rights. They are also inspired for peace to be realised in human hearts as well as in the social and political spheres of life. Pope Francis's description of peace and praxis, mentioned earlier, resonates with contextual underpinnings related to homelessness because it points to more than just peace as it is in Isaiah 65:17-25.

\section{Peace and the new city}

Isaiah $65: 17-25$ is a post-exilic text that reflects on the past experiences of pain but also on the hope for the future as well (Lang 2005:34). This text addresses the question whether there is any reason to hope or at least look forward to the future. In this misty picture of the future peace is announced, despite being corrupted by the past events of the destruction of Jerusalem in 587 BC which led to exile captivity and terrible present realities of a free but hurting community. This vision of hope points to the eschatological event, where peace in its holistic ways will be implemented. In this vision the city reflects the perfection of peace, which allows no harm and destruction. Brueggemann (1993:77) suggests that God's intention for the city is for faithfulness, justice and righteousness, for social structures and relations that will work for the good of all, for a place in which resources are shared fairly and God's presence is known. Indeed, fairness in sharing resources of the city to all its citizens is a sign of 'newness' in comparison to injustice and exploitation which plagued Israel at that time. Brueggemann is, therefore, right in suggesting the imagination of the new things that God intends for the city (Brueggemann 1993:80). At the core of these new things is eradication of poverty, injustice and misery of the poor and marginalised as portrayed in Isaiah 65. Thus, the people of God and other agents of change are commanded to seek the welfare of the city (Jr 29:7; see also Wright 2010:232).

\section{Encounterological reflection on Isaiah 65:17-25}

The encounterological reflection answered by participants focussed on the following questions:
- What is this text about?

- Who are the intended readers?

- What does God intend to do? Why?

- What are the things or issues in our context which need to be changed for the better? Why?

- How does the work of God change the situations or conditions of the people?

- What could we learn from how God works to change people's situations or conditions?

- Drawing from God's vision, what could be done to have peace in our city?

- What could you do in support of these actions?

\section{What is this text about?}

When the participants (the group of homeless people) were asked what Isaiah $65: 17-25$ is about, they pointed out that it is about the fulfilment of God's promises about the new paradise where there will be no more suffering. They added that it is also about God's promise for a better and longer life. It shows that God will rejoice in his people and that prayers will be answered before they are completely said. Further, it is about blessings to future generations, a life of peace and tranquillity, no more curses, harmony between beasts and people, and a fruitful life. It is evident in the participants' responses that a broader vision of peace is the ultimate goal which, if realised, will result in harmony between God, humanity and nature.

\section{Who are the intended readers?}

When the participants were asked to identify the intended readers of Isaiah 65:17-25, they correctly pointed to all the tribes of Israel (Group 1 \& Group 3), all the people of God (Group 2), and the people who believe in God (Group 1). The participants' responses clearly show that Isaiah 65:17-25 is still relevant today, and that the message contained therein could be appropriated by contemporary believers in any situation in which they find themselves. Their argument suggests that as much as this message was first addressed to Israel, it includes all people even today.

\section{What does God intend to do? Why?}

The participants then paid attention to the next question (based on this text) that required them to reflect on what God intends to do and why. Group 3 remarked that in verse 16 God was giving the sinners of Jerusalem a chance to repent because he loved them and he wanted to bless them. He told them to ask for forgiveness so that he could bless them and remove the curses from them. He also wanted them to live in his promised paradise for an everlasting life (as recorded by Group 3). Group 2 stated:

'God was promising the people a better life. He wanted his people not to lose hope and to realise that there is a better life ahead and he intended to create a life full of heavenly peace because God was happy with his creation and he wanted his people to know the plans he has for them.' 
Group 1 added:

'God intended to create a new earth and heaven, to bring an end to weeping and crying, to bring eternal life, to give Jerusalem peace and love, to answer their prayers before they finish praying, to rejoice in his people and to end their suffering.'

Participants' reflections speak of God's love shown in his willingness to forgive and to bless humanity with a gift of a 'new earth and new heavens' where life would be peaceful forever. The 'new earth and heaven' symbolises a transformed reality. It is an allegory of change.

\section{What are the things or issues in our context which need to be changed for the better? Why?}

The following question that the participants had to answer focused more on the issues in their personal contexts that needed to be changed for the better and the reasons for those changes. In response to this question, while recognising that premature death, homelessness, poverty, unfruitfulness, and unanswered prayers are caused by sin, Group 3 reasoned that these burdens are not the results of God's plans for us. They continued by saying that 'if even birds are cared for by God how much more will he then care for us!' The group supported this view by stating, 'We really, as verse 16 says, need to be repentant and seek God's forgiveness so that we can get all the promises that are in verses 17-24'. Group 1 added saying, 'We must commit our lives to God. We must see God as our saviour and by obeying the word we are saved.' However, it was interesting to observe the contextualisation of this text by Group 2. They, on the one hand, argued:

'People are in suffering because they have strayed away from God; as a result, they are dying from incurable diseases, they are living in poverty due to idleness, and their lifespans have been cut short because of the way in which they conduct their lives by indulging in sexual immorality.'

They further pointed out things that needed to be changed, such as: people should desist from fornication, people should remain faithful by offering their tithes and people should be productive in order to enjoy the fruits of their labour. These reflections showed that the participants were aware of other contextual issues which may hamper the realisation of a better life for all. These issues are by nature interlinked and multidimensional; that is, spiritual, socioeconomic and physical.

\section{How does the work of God change the situations or conditions of the people?}

Concerning how the work of God changes people's situations or conditions, the participants stated that God acts through 'blessing them and giving them peace and by providing them a better life for everyone who seeks him and rejects evil or harm'. Group 1 explained:
'[He also] brings hope and peace to us and God always does positive things so we must try to aim positively and promise ourselves to only commit to good things (to focus in future).'

Furthermore, 'the work of God teaches us how to live by faith, how to be productive and how to behave in the face of challenges of everyday life' (Group 2). It is evident in these reflections that participants see God as the 'transformer' of life's situations that are evil and dehumanising in the process of realising peace. The reflections also depict God as a 'teacher' and a 'model' for behaviour as far as peace is concerned.

\section{What could we learn from how God works to change people's situations or conditions?}

In terms of what could be learned from how God works to change people's situations or conditions, participants stated that this can be realised 'through repentance and God's forgiveness'. They said, 'We learn that God wants us to live a happy and everlasting life; and that he has good intentions for creation, animals and people by living together harmoniously' (Group 3). Furthermore, Group 1 explained:

'Our God makes promises, commits himself and delivers on his promises for the goodness of life. We must also try to solve issues according to his ways. God said he will never put us to shame and if we really trust in him things will change. If you believe in him it does not mean you will not have problems or challenges but even in life's storms he is Lord and he always works in his own (mysterious) ways we might not understand. Our God is able. He is mighty and able.

Further, we learn that if we leave our evil ways and turn to God he will heal the land and restore all the good things that have been promised to us in abundance.'

These reflections show that the participants regarded repentance and trust in God as prerequisites for the peaceful life that God intended for the whole creation. In the eyes of the ordinary readers trust in the sovereign and omnipotent God appears to be an important element for restoration and peace.

\section{Drawing from God's vision, what could be done to have peace in our city?}

With regard to what could be done to have peace in our city in relation to God's vision, participants (the joint group) named police visibility and law enforcement, establishing street committees to oversee peace, abiding by God's ten commandments, putting God first (the constitution of the country is important, but God's word is more important), respecting other religions and giving shelter, clothes and other necessities to those in need. They also pointed out that the Church needs to be true to its mission, to have leaders like Solomon who seek wisdom from God (contrary to today's leaders who seek riches). They emphasised that we 
as a community need wisdom to challenge leaders in public offices about injustice and inequality. Furthermore, they noted that animals should be allowed to live in their natural habitat, jobs must be created (not job opportunities), empty flats in the city must be occupied by the people in need (at a nominal subsidised cost), and we need to learn to imitate good things and identify bad things. In these reflections, participants pointed out that the realisation of peace in Tshwane would necessitate wisdom and an integration of actions from various institutions of Tshwane such as the police and the Church. Community members, in obedience to God's commandments, are expected to act to maintain and oversee peace between themselves and the rest of creation.

\section{What could you do in support of these actions?}

Finally, with regard to what participants could do in support of the abovementioned actions, participants suggested the following:

- We should initiate change rather than wait for it.

- We must be the change that we want to see.

- We should love selflessly. We need to start loving without conditions (Mt 22:34-40).

- We should speak one language, in one mind to bring about peace (as in the 2010 World Cup when there was harmony between community members across South Africa).

- We need to be united.

- We need to learn sharing (land, clothes, and shoes).

- We must be model parents.

- We should bring people closer to God.

- We should pray for the New Jerusalem to be realised today.

- To change social issues in the city we must deal with diversity first.

- We need to follow Jesus as the advocate for the poor and voiceless (Pr 31:8).

- We need to seek to build, not to destroy.

In these reflections, participants recognised that peace is not achieved by chance. It is a fruit of conscious effort and choice for positive change, love, unity, service, respect, diversity, advocacy and of maintaining peace. Overall, we observed that the participants' reflections related to concrete issues associated with peace in Tshwane. The reflections were 'down to earth', yet not simplistic. They depict, in the manner of speech of ordinary men and women, far reaching issues associated with peace in Tshwane. In the section which follows, we present a critical dialogue between voices of the trained and ordinary readers. The emerging voices of the homeless take centre stage in this dialogue.

\section{Synthesis: Emerging voices of ordinary readers about a vision for peace}

Mashau (2014:206) states that the process of 'bringing synergy between the trained reader and the ordinary reader of the text is important in allowing a space for the emerging voices of the ordinary readers to be heard'. According to West (1995:209), this step allows for an interface between the trained and ordinary readers of the Bible. When we did the synthesis, it became clear that participants (ordinary readers) in this research extended what the text is about to include a broader vision of peace that is not limited only to Israel or believers of $\mathrm{YHWH}$, as often happens when the text is read through trained readers' lenses. However, there are aspects in common such as:

- peace as the activity of God

- restoration of joy (where pain and loss do not exist) as a symbol of peace

- welfare of all the city residents.

Furthermore, the synthesis reflects numerous new insights from the homeless community as far as the interpretation of Isaiah $65: 17-25$ is concerned. However, it is necessary to point out that there is a vast gap between the trained and ordinary readers of the Bible in understanding, interpretation and application of the text, possibly as a result of each side's approach in reading the Bible. The ordinary readers - in this case all Africans - seem to have connected the vision of peace in Isaiah 65:17-25 with the real needs in the city in relation to homelessness. They show, as it is the case with African Initiated Churches, that 'God cares about those needs and is making provision for his people by helping to meet them' (Oduro et al. 2008:18). As a result, the text is received at face value with no consideration to the background. Further, the synthesis reveals that trained readers study the text scientifically with Bible commentaries and other study materials whilst the ordinary readers judge it by using the lenses of faith. It may be necessary for a trained reader to highlight and emphasise the background of the whole book of Isaiah, and how possible it is (if not beyond possibility) that this book was written by more than one author. In contrast, the ordinary readers lacking the skills that trained readers have will take the Bible literally. For these readers, what matters is that the Bible is 'God's word', and as it is the message from God, it is relevant and applicable.

The ordinary readers viewed the Bible not as an outdated book for the 'primitive' era. The Bible is real to them. Therefore, its message is important. With reference to Isaiah 65:17-25, they believe that it carries a broader vision of peace. Such peace is not limited to one aspect of life only; it is holistic; it is about seeking to reconcile God, humanity and nature. For these ordinary readers, harmony in the world cannot only be achieved when God and humanity are in one accord. As much as they believe in the relationship between God and humanity, and humans within themselves, nature cannot be neglected. They believe that the world does not only encompass humanity but the whole creation. This view resonates with that of the African Christian worldview which sees life as a unit (see Bediako 2004:17).

At the core of this worldview is the affirmation that God loves humanity and the rest of creation, and through his 
love he is ready to accept us all and transform our reality. Transformation is then the activity of God as he works in bringing about the new world, new heaven and new earth. In the ordinary readers' application of the text, God can be understood to be the 'transformer, teacher and a model for moral behaviour' in fighting evils and dehumanising acts against humanity and nature. Hence, for them this passage of scripture is still appropriate for the contemporary world. This passage is relevant in reference to the contextual issues they face, which are multidimensional in nature, as it pertains to the spiritual, socioeconomic and physical realms. Therefore, for them and many others on the margins of society in Tshwane, this promise of change can be the foundation of (a reason to) hope and a pillar of peace.

This hope is also the hope of the city. The City of Tshwane may find refuge in this hope of restoration and peace. However, the ordinary readers highlighted that peace does not happen by chance. It takes countless conscious efforts and determination for which to strive. They, therefore, emphasised that various institutions of Tshwane should collaborate towards the realisation of peace in Tshwane. They specifically referred to the following sources, as they could contribute greatly to the realisation of peace in the city:

- institutions of education (especially universities)

- business institutions (both public and private)

- government institutions (particularly the police)

- churches as well as other community figures.

The foregoing clearly shows that in relation to the vision of peace presented in Isaiah 65:17-25, ordinary readers speak of its realisation in concrete terms as something to work towards in the here and now. It is also clear that they are prepared to work towards realising such peace in Tshwane as active, responsible citizens of the city.

\section{Conclusion}

The aim of this research was to communicate the wishes and desires of the homeless community of the CoT about peace in the city. Using Isaiah 65:17-25 as a hermeneutic key, we sought to explore the issue of vision for peace from the perspective of the homeless in the CoT. Basic theological and encounterological reflections of Isaiah 65:17-25 were undertaken by both parties of trained readers and ordinary readers respectively.

The findings, in terms of insights from the homeless community about a vision for peace in Tshwane revealed that peace may only happen as a result of all conscious efforts and determination for which to strive. Insights from the homeless community for the realisation of peace in Tshwane specifically suggested that: institutions of education (especially universities), business institutions (both public and private), government institutions (particularly the police), and churches as well as other community figures should work together in synergy towards the realisation of peace in the city. At the core of the insights, from participating ordinary readers, was the realisation of the holistic and integrated vision for peace in the city, and to speak of it in concrete terms as something to work towards in the here and now.

The recommendations derived from the research were: the homeless people must be partisans to such a holistic and integrated vision for peace and should be seen as active, responsible citizens of the city, willing to undertake actions that are in support of this vision.

The contribution of this research lies in unearthing the insights from a local homeless community, as highlighted here above, which could make a contribution towards the development of an integrated praxis needed for transformative urban missiology in the CoT that is focussed on peace.

Based on the findings of this research and the information contained therein, it is clear that the input by the homeless is not yet part of 'this relentless and irrevocable journey to the kingdom of a better life for all citizens of the metropolitan City of Tshwane' (City of Tshwane 2014:23). The input by the homeless could help extend peace in the City of Tshwane where its inhabitants will 'neither harm nor destroy ...'

\section{Acknowledgements Competing interests}

The authors declare that they have no financial or personal relationships which may have inappropriately influenced them in writing this article.

\section{Authors' contributions}

Both authors, L.M. and T.H. (University of South Africa), conducted the original empirical work reflected in the article and wrote an initial draft and made substantial conceptual contribution. They were also both responsible for the revision of the article. L.M. contributed as the author to the final text and prepared the article for submission.

\section{References}

Bediako, K., 2004, Jesus and the Gospel in Africa: History and experience, Orbis Books, Maryknoll, NY.

Beyer, B.E., 2007, Encountering the Book of Isaiah: A historical and theological survey, Baker Academic, Grand Rapids, MI.

Brueggemann, W., 1987, Hope within history, John Know Press, Atlanta, GA.

Brueggemann, W., 1993, Using God's resources wisely: Isaiah and urban possibility, Westminster/John Knox, Louisville, KY.

Campolo, T., 2008, Red Letter Christians. A citizen's guide to faith and politics, Rega Books, Ventura, CA.

City of Tshwane, 2013, Homelessness policy for CoT and report on public participation Council 28 March 2013, City of Tshwane, Pretoria.

City of Tshwane, 2014, State of the capital city address, viewed 11 April 2015, from http://www.tshwane.gov.za/Documents/State\%20of\%20the\%20Capital\%20 City\%20Address\%20-\%2003April\%202014\%20-\%20FINAL\%20VERSION.pdf

Chu llo, S., 2011, The church and development in Africa: Aid and development from the perspective of Catholic social ethics, Pickwick Publications, Eugene, OR.

Clarke, A., 1832, Bible commentary, viewed 11 April 2015, from http://www. preteristarchive.com/Books/1810_clarke_commentary 
Corbett, S. \& Fikkert, B., 2012, When helping hurts: How to alleviate poverty without hurting the poor ... and yourself, Moody Publishers, Chicago, IL.

Davidson, F., Stibbs, A.M. \& Kevan, E.F. (eds.), 1965, The New Bible Commentary, 2nd edn., The Inter-Varsity Fellowship, London.

Durham, J.I. \& Porter, J.R., 1970, “'Shalom" and the presence of God', in J.I. Durham (ed.), Proclamation and presence, p. 280, John Knox, Richmond, VA.

Francis (Pope), 2013, The apostolic exhortation, Evangelii Gaudim, of the holy Father Francis to the bishops, clergy, consecrated persons and the lay faithful of the proclamation of the gospel in today's world, Vatican Press, Rome.

Keller, T., 2010, Generous justice: How God's grace makes us just, Hodder \& Stoughton, London.

Koehler, L., Baumgartner, W., Stamm, JJ. \& Richardson, M.E.J., 1994, The Hebrew and Aramaic Lexicon of the Old Testament, viewed 22 April 2015, from http://scholar. google.co.za/scholar?q=The+Hebrew+and+Aramaic+Lexicon+of+the+Old+Testam ent\&btnG=\&hl=en\&as_sdt=0\%2C5

Koopman, N., 2010, 'Some contours of public theology in South Africa, research report', International Journal of Public Theology 14, 123-138. http://dx.doi. org/10.1515/ijpt.2010.9

Kritzinger, J.N.J., 2008, 'Faith to faith - Missiology as encounterology', Verbum et ecclesia JRG 29(3), 764-790. http://dx.doi.org/10.4102/ve.v29i3.31

Lang, P., 2005, The eschatological implications of Isiah 65 and 66 as the conclusion of the book of Isaiah, European Academic Publishers, New York, NY.

Mashau, T.D., 2014, 'More than just a piece of land: Power dynamics in the land discourse within the City of Tshwane', Missionalia 42(3), 192-211. http://dx.doi. org/10.7832/42-3-64
Oduro, T., Pretoruis, H., Nussbaum, S. \& Born, B., 2008, Mission in an African way. A practical introduction to African Instituted Churches and their sense of mission, Christian Literature Fund \& Bible Media, Pretoria.

Ryken, L. \& Longman, T. (eds.), 1995, 'Peace', in L. Ryken \& T. Longman (eds.), The Dictionary of Biblical Imagery, p. 632, III, InterVarsity Press, Downers Grove, IL.

Scott, T., 1866, Bible commentary, viewed 11 April 2015, from https://archive.org/ details/holybibleaccordi06scotuoft

Utley, B., 2010, Old Testament special topics, Free Bible commentary, Marshall, Bible Lessons International, Marshall.

Webb, B.G., 1997, The message of Isaiah: On eagle's wings, InterVarsity Press, Downers Grove/Leicester.

West, O.G., 1995, Biblical hermeneutics of liberation: Modes of reading the Bible in the South African context, 2nd edn., Orbis Books, Maryknoll, NY/Cluster Publications, Pietermaritzburg.

West, G. \& Ujamaa Centre Staff, 2011, Doing contextual Bible study: A resource manual (Revised version February 2011), The Ujamaa Centre for Biblical and Theological Community Development and Research, Pietermaritzburg.

Wolterstorff, N., 1983, Until justice and peace embrace, Eerdmans, Grand Rapids, MI.

Wood, D.R.W., [1962] 1996, New Bible Dictionary, 3rd edn., Inter-Varsity Press, Downers Grove, IL.

World Council of Churches, 1990, Now is the Time: The final document and other texts from the World Convocation on Justice, Peace and the Integrity of Creation, Seoul, Republic of Korea, 5-12 March 1990, WCC Publications, Geneva.

Wright, C.J.H., 2010, The mission of God's people. A Biblical theology of the Church's Mission, Zondervan, Grand Rapids, MI. 